\title{
Comparison of analyses types in carrot experiment: square lattice versus randomized blocks design
}

\author{
Agnaldo DF Carvalho'; Giovani O Silva ${ }^{2}$
}

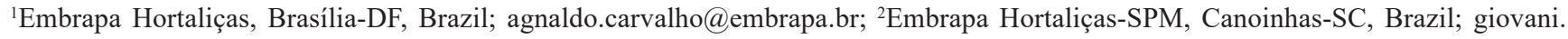
olegario@embrapa.br

\begin{abstract}
The square lattice $4 \times 4$ design was compared to a randomized block design, for carrot $F_{1}$ hybrids. Sixteen experimental carrot hybrids were evaluated in Brasília, in 2014/15 and 2015/16 agricultural years. A square lattice $4 \times 4$ design with three replications was used. The experimental plot consisted of $1.5 \mathrm{~m}^{2}$ useful area. The experimental area was installed on the second half of November 2014 and 2015. Cultural practices were the usually given to the carrot crop in Brazilian savannah region. The incidence of leaf blight was evaluated 90 days after sowing date and, after 100 days, roots were harvested and yield components evaluated. We evaluated the three possible analyses in lattice: 1) as randomized block design; 2) intrablock analysis with adjusted treatments and blocks within unadjusted repetitions; 3) analysis with recovery of interblock information with adjusted treatments. The analysis in lattice permitted to reduce the mean squares of error and coefficients of variation; moreover, these were more efficient than the randomized block design experiments for most evaluated characters. Thus, use of the analysis in lattice is preferred in experiments with carrot when evaluating large number of treatments.
\end{abstract}

Keywords: Daucus carota, experimental design, incomplete block.

\section{RESUMO}

Comparação de tipos de análises em experimento com cenoura: látice quadrado versus blocos casualizados

Comparou-se o delineamento em látice quadrado $4 \times 4$ ao de blocos ao acaso para híbridos $\mathrm{F}_{1}$ de cenoura. Dezesseis híbridos experimentais de cenoura foram avaliados em Brasília nas safras 2014/15 e 2015/16. Foi utilizado delineamento de látice quadrado $4 \times 4$ com três repetições. A parcela experimental foi composta por parcela útil de $1,5 \mathrm{~m}^{2}$. A área experimental foi instalada na segunda quinzena de novembro de 2014 e 2015 Os tratos culturais foram os normalmente indicados para a cultura da cenoura na região do cerrado brasileiro. Aos 90 dias após a semeadura foi realizada a avaliação de incidência da queima das folhas e, aos 100 dias, as raízes foram colhidas e quantificadas para os caracteres componentes de rendimento. Realizou-se as três análises possíveis do experimento em látice: 1) como blocos casualizados; 2) intrablocos com tratamentos ajustados e blocos dentro de repetições não-ajustados; 3) análise com recuperação de informação interblocos com tratamentos ajustados. As análises em látice permitiram reduzir os quadrados médios dos resíduos e coeficientes de variação experimental. Ainda, foram mais eficientes do que os experimentos em blocos casualizados para maioria dos caracteres avaliados. Desse modo, a utilização da análise em látice deve ser preferida em experimentos com cenoura quando avaliado grande número de tratamentos.

Palavras-chave: Daucus carota, delineamento experimental, blocos incompletos.

Received on December 7, 2016; accepted on September 9, 2017

$I^{\mathrm{n}}$ n field experiments, the use of complete randomized block design for local control, is common, considering environmental homogeneity within each replication. However, on experiments involving large number of genotypes (progenies, hybrids, clones or lineages), the local control can be compromised, since the area of each replication becomes considerably large, without guaranteeing the homogeneity within the same, implicating the quality of the collected information (Silva et al., 2000).
With the increase in the number of treatments, alternatives that minimize the heterogeneity within each replication can be used, thus increasing the accuracy of the performed analyzes. An alternative for greater local control is the use of incomplete blocks, more specifically square latices. This design was suggested by Yates in 1936 to allow the evaluation of large set of treatments, greatly increasing the reliability of results (Sharma et al., 2016).

The use of lattice designs is common in experiments with corn or soybeans, since they usually require the evaluation of large number of genotypes, either for cultivar release or for evaluation of many genotypes generated in large diallel crosses or, in the evaluation of tens or hundreds progenies in recurrent selection programs. However, in greenhouses these designs are rarely used, except for potatoes (Bearzoti et al., 1997). For vegetables, the use of lattice experiments is reported for hot pepper by Nsabiyera et al. (2013), for tomato by Ceballos-Aguirre et al. (2012), potato by Navarro et al. (2015) and carrot by 
Hay \& Pethybridge (2005).

Arguments that justify conducting the experiment in a lattice design are that they have greater local control in heterogeneous areas and greater versatility at the time of analysis, in other words, can be analyzed in several ways. The most common are: randomized block analysis, intrabloc analysis with adjusted treatments and blocks within unadjusted replications, and analysis with retrieval of interblock information with adjusted treatments. Methodologies for these analyzes are described in Pimentel-Gomes (2009).

Experiments conducted in incomplete block design, in this case the lattice, have versatility, if the lattice efficiency is small or null, to be analyzed as randomized blocks (DBC). In this case, lattices increase safety if the researcher has safeguard about the environmental homogeneity at the place where the experiment will be conducted (Marques Júnior et al., 1999).

The objective of this study was to evaluate the efficiency of lattice design by three different statistical methodologies to verify the efficiency of this design in carrot experiment.

\section{MATERIAL AND METHODS}

Two experiments were evaluated in the agricultural years 2014/15 and 2015/16 in Brasília-DF (15'55'46"S, $48^{\circ} 08^{\prime} 31^{\prime \prime} \mathrm{W}, 1.000 \mathrm{~m}$ altitude). The chemical soil fertility analysis revealed in the first year $\mathrm{pH}=4.9 ; \mathrm{P}, \mathrm{K}$ and $\mathrm{Na}=24.50 ; 194$ and $7\left(\mathrm{mg} \mathrm{dm}^{-3}\right)$, respectively. In addition to $\mathrm{Al}, \mathrm{H}+\mathrm{Al}$, $\mathrm{Ca}$ and $\mathrm{Mg}\left(\mathrm{cmol} \mathrm{dm}^{-3}\right)$ contents of $0.65 ; 6.50 ; 2.3$ and 1.10 , respectively. Fifteen experimental carrot hybrids and one control cultivar (hybrid Verano) were evaluated, totaling 16 treatments distributed in a $4 \times 4$ triple square lattice design (16 treatments).

Soil preparation consisted of plowing, two months before sowing. Seedbeds were one meter wide and $20 \mathrm{~cm}$ high. The commercial formula 04-14-08 (NPK + B and Zn) at the dose of $1,300 \mathrm{~kg} \mathrm{ha}^{-1}$ was used in planting fertilization, incorporated on seedbeds one day before planting. The experimental plot was composed of $1 \times 1.5$ meters area, which generated a useful plot of $1.5 \mathrm{~m}^{2}$. Manual sowing was done in the third week of November of each agricultural year, in transversal grooves to the bed, $1 \mathrm{~cm}$ deep. We adopted double rows spaced $20 \mathrm{~cm}$ between them and single rows of $10 \mathrm{~cm}$.

The experiments received additional spraying irrigation when necessary. Plantlets were thinned 30 days after sowing date, leaving a population density equivalent to 600 thousand plants per hectare. After thinning, ammonium sulfate $\left(55 \mathrm{~kg}\right.$ of $\left.\mathrm{N} \mathrm{ha}^{-1}\right)$ was applied in cover fertilization. Weeds were controlled with $990 \mathrm{~g}$ i. a ha ${ }^{-1}$ of the herbicide Linuron, 15 days after sowing date. After this procedure, beds were kept clear of weeds by hand weeding. Other cultural treatments were those normally used for carrot cultivation in the Brazilian savannah region.

Ninety days after sowing, leaf blight (QDF) was evaluated, assigning scores from 1 to 5 ( $1=>90 \%$ severity, $2=50$ $90 \%$ severity, $3=12.5-50 \%$ severity, $4=3.8-12.55 \%$ severity and $5=<3.8 \%$ severity). Roots were harvested 100 days after sowing, evaluating total mass of roots [(TMR) weighing all harvested roots in each plot]; mass of commercial roots [(MCR) weighing all roots of each plot with commercial pattern, according to the carrot classification by CEAGESP (CEAGESP, 1999)]; mass of noncommercial roots [(MNR), by the weight difference between TMR and MCR]; proportion of MCR/TMR (PROP); average total mass of roots [(MTMR) weight of 30 individual roots taken at random within each plot]; and mean mass of commercial standard roots [(MMCR) average weight of 30 individual roots, taken at random within each class established as commercial].

Data were evaluated for the assumptions of the analysis of variance and analyzed considering three possible analyzes of lattice experiments: 1) randomized block analysis $(\mathrm{DBC})\left(1^{\mathrm{a}}\right.$ A); 2) intrabloc analysis with adjusted treatments and blocks within unadjusted replications $\left.\left(2^{\mathrm{a}} \mathrm{A}\right) ; 3\right)$ analysis with interblock information recovery, with block within replications and adjusted treatments $\left(3^{\mathrm{a}} \mathrm{A}\right)$. The first two analyzes were performed using PROC GLM procedure of statistical computer package SAS v. 9.4 (SAS, 2014), while the third analysis, as well as ScottKnott's means clustering tests, at 5\% probability were performed using Genes V. computational statistical package V. 2013.5.1 (Cruz, 2013).

\section{RESULTS AND DISCUSSION}

Summary of variance analysis for the 16 carrot hybrids in the 2014/15 crop are presented in Table 1. The three types of analyzes revealed significant differences between treatment effects for all evaluated characters. However, there were differences regarding their significance, with ' 3 a $A$ ' being the only one capable of revealing significance at $1 \%$ by the $\mathrm{F}$ test for all characters. Mean squares of residues presented lower values for ' $2{ }^{a} \mathrm{~A}$ ' and ' $3 \mathrm{C}^{\mathrm{a}} \mathrm{A}$ ' in comparison to ' 1 a $A$ ', giving greater precision to the experiments analyzed with this design.

Coefficients of experimental variation were lower for the experiments analyzed in lattice $\left(2^{\mathrm{a}} \mathrm{A}\right.$ and $\left.3^{\mathrm{a}} \mathrm{A}\right)$ in comparison to $\mathrm{DBC}\left(1^{\mathrm{a}} \mathrm{A}\right)$ for all evaluated characteristics. Lower values for the coefficient of experimental variation in lattice designs are frequent in literature. However, according to Matei et al. (2017), these values alone are small for the use of more complex experiments such as lattices, justifying this type of design only as a precaution, when there is doubt about the homogeneity of the place where the test will be evaluated.

Lattice design was more efficient than randomized block for all evaluated characters. These values varied from $100.22 \%$ for MMCR to $127.85 \%$ for QDF. According to Bueno Filho \& Vencovsky (2000), in cases where the efficiency of lattice is superior in comparison to randomized block design, it is not possible to ignore the effect of blocks within replications and lattice analysis must be required.

For the 2015/16 crop (Table 2), lattice analyzes allowed to detect differences in a greater number of characters than analyses in DBC, being the last, the characters MCR 
and PROP not significant by $\mathrm{F}$ test for differences between treatments. The coefficients of experimental variation for experiments analyzed in lattice were lower for all evaluated characters, showing greater local control of this delineation in relation to ' 1 a $A$ '. In relation to the efficiency of lattice, this scheme was more accurate than the experiment analyzed in randomized blocks for all evaluated characters, being this efficiency superior to $110 \%$ for all variables and reaching $148.36 \%$ for MCR. Although occurring loss of number of degrees of freedom of the residue, which reduces the power of statistical tests, the greater efficiency of lattice and reductions of the average squares of residue and of the coefficients of variation justify the use of lattice in experiments with carrots, as well as Khan et al. (2015) justify these designs in potato, wheat and corn crops.

The evaluation of lattice experiments is indicated when the number of genotypes to be tested is large or when the size of blocks becomes too large, to the point where researcher doubts about the homogeneity of the experimental area (Silva et al., 2000). However, in the present study, as the number of genotypes was moderate (16), as well as the area of each replication considered to be small, close to $24 \mathrm{~m}^{2}$ ( $1.5 \mathrm{~m}$ length per plot x 16 genotypes), the use of lattice design is recommended even in conditions where RCBD is normally used, as is commonly the case in carrots. According to Marques Júnior et al. (1999), lattice design provides more security for the researcher when there is doubt about homogeneity of the place where the experiment will be conducted. If there is any heterogeneity, analysis of lattice allows to evaluate more accurately and reliably the estimates of the means of treatments. However, if there is no problem regarding heterogeneity of the evaluation site, data can be analyzed as a randomized complete block design, without prejudice to the means or variance estimates.

In case of crops as soybeans (Melo Pinheiro et al., 2013), castor beans (Nobrega et al., 2010), corn (Vilarinho et al. (2008), beans (Campos et al.,
2016), wheat (Pimentel et al., 2014), among others, the use of lattice design is routinely performed due to doubts regarding homogeneity of the soil where the experiment is planned, the high number of genotypes to be evaluated, or the possibility of flexibilizing the analyzes RCDB or incomplete blocks, depending on the efficiency of lattice design. However, in the case of vegetables, except potatoes, publications using these designs are scarce or nonexistent. The lack of use of more complex designs in experimentation with vegetables comes from the tradition of experiments of these cultures being small and considered homogen between replications due to the reduction of environmental effects, through the use of high doses of fertilizers, use of complementary irrigation and effective control of pests and diseases with pesticides. However, the results of the present study demonstrate that in practice, it is not always possible to obtain sufficient homogeneity, even when evaluating moderate number of treatments.

Table 1. Summary of the variance analysis of lattice as a randomized complete block $\left(1^{\mathrm{a}} \mathrm{A}\right)$, intrabloc lattice with adjusted treatments $\left(2^{\mathrm{a}}\right.$ A), and intrablock analysis of the lattice with adjusted treatments ( $\left.3^{\mathrm{a}} \mathrm{A}\right)$, for 16 carrot hybrids evaluated in the 2014/15 season. Brasília, Embrapa, 2016.

\begin{tabular}{|c|c|c|c|c|c|c|c|c|c|}
\hline \multirow{2}{*}{ Analyses } & \multirow{2}{*}{ FV } & \multirow{2}{*}{ GL } & \multicolumn{7}{|c|}{ Characters (QM) } \\
\hline & & & TMR $^{1}$ & MCR & MNR & PROP & MTMR & MMCR & QDF \\
\hline \multirow{3}{*}{$1^{\text {a } \mathrm{A}}$} & Rep. & 2 & 0.8 & 98.63 & 111.7 & 0.030 & 431.79 & 125.13 & 25.89 \\
\hline & Treat. & 15 & $315.91 * *$ & $205.78 * *$ & $41.59^{*}$ & $0.018 * *$ & $178.62 * *$ & $136.51 *$ & $622.98 * *$ \\
\hline & Residue & 30 & 42.45 & 34.28 & 20.01 & 0.005 & 44.97 & 51.51 & 73.03 \\
\hline \multirow{4}{*}{$2^{\text {a } \mathrm{A}}$} & Rep. & 2 & 0.80 & 98.63 & 111.7 & 0.030 & 431.79 & 125.13 & 25.89 \\
\hline & Bloc/rep (not adjust.) & 9 & $199.79 * *$ & $109.74 * *$ & $46.31 * *$ & $0.009^{*}$ & $167.31 * *$ & $91.17^{\text {ns }}$ & $476.81 * *$ \\
\hline & Treat. (adjust.) & 15 & $227.06^{* *}$ & $171.66^{* *}$ & $35.27 * *$ & $0.018 * *$ & $118.54^{* *}$ & $114.62 *$ & $415.78 * *$ \\
\hline & Intrablock error & 21 & 38.47 & 26.32 & 13.28 & 0.004 & 35.45 & 50.15 & 47.98 \\
\hline \multirow{4}{*}{$3^{\mathrm{a}} \mathrm{A}$} & Rep. & 2 & 0.80 & 98.63 & 111.70 & 0.030 & 431.79 & 125.13 & 25.89 \\
\hline & Bloc/rep (adjust.) & 9 & $51.72^{\mathrm{ns}}$ & $52.87^{\mathrm{ns}}$ & $35.70^{*}$ & $0.008^{*}$ & $67.19^{\text {ns }}$ & $54.68^{\text {ns }}$ & $131.48^{*}$ \\
\hline & Treat. (adjust.) & 15 & $315.91 * *$ & $199.83 * *$ & $39.98 * *$ & $0.019 * *$ & $154.46^{* *}$ & $136.52 * *$ & $561.31^{* *}$ \\
\hline & Intrablock error & 21 & 38.47 & 26.32 & 13.28 & 0.004 & 35.45 & 50.15 & 73.03 \\
\hline & \multirow{2}{*}{$\begin{array}{c}\text { Mean } \\
\text { CV lattice intrablock } \\
(\%)\end{array}$} & & 59.34 & 26.45 & 32.88 & 0.434 & 59.30 & 95.72 & 20.99 \\
\hline & & & 10.45 & 19.39 & 11.08 & 13.364 & 10.04 & 7.40 & 33.00 \\
\hline & CV block (\%) & & 10.98 & 22.13 & 13.60 & 16.155 & 11.31 & 7.50 & 40.71 \\
\hline & Efficiency (\%) & & 102.46 & 113.21 & 126.74 & 123.627 & 111.11 & 100.22 & 127.85 \\
\hline
\end{tabular}

${ }^{1} \mathrm{TMR}=$ total mass of roots $\left(\mathrm{t} \mathrm{ha}^{-1}\right) ; \mathrm{MCR}=$ mass of commercial roots $\left(\mathrm{t} \mathrm{ha}^{-1}\right) ; \mathrm{MNR}=$ mass of noncommercial roots $\left(\mathrm{t}\right.$ ha $\left.{ }^{-1}\right) ; \mathrm{PROP}=$ proportion among commercial and total roots; $\mathrm{MMTR}=$ mean mass of total roots $\left(\mathrm{g} \mathrm{root}^{-1}\right) ; \mathrm{MMCR}=$ means mass of commercial roots $\left(\mathrm{g}\right.$ root $\left.{ }^{-1}\right)$; and $\mathrm{QDF}=$ tolerance to leaf blight (\%). 
Table 2. Summary of variance analysis of lattice as a randomized complete block $\left(1^{\text {a }} \mathrm{A}\right)$, intrabloc lattice with adjusted treatments $\left(2^{\mathrm{a}}\right.$ A), and intrablock analysis of the lattice with adjusted treatments ( $\left.3^{\mathrm{a}} \mathrm{A}\right)$, for 16 carrot hybrids evaluated in the 2015/16 season. Brasilia, Embrapa, 2016.

\begin{tabular}{|c|c|c|c|c|c|c|c|c|c|}
\hline \multirow{2}{*}{ Analyses } & \multirow{2}{*}{ FV } & \multirow{2}{*}{ GL } & \multicolumn{7}{|c|}{ Mean squares } \\
\hline & & & TMR $^{1}$ & MCR & MNR & PROP & MTMR & MMCR & QDF \\
\hline \multirow{3}{*}{$1^{\mathrm{a}} \mathrm{A}$} & Rep. & 2 & 1440.10 & 747.71 & 124.32 & 0.055 & 696.04 & 440.65 & 15.47 \\
\hline & Treat. & 15 & $200.35^{*}$ & $48.87^{\mathrm{ns}}$ & $119.65^{* *}$ & $0.014^{\text {ns }}$ & $105.62^{\mathrm{ns}}$ & $131.73^{\mathrm{ns}}$ & $837.77 * *$ \\
\hline & Residue & 30 & 83.58 & 47.59 & 44.47 & 0.013 & 140.27 & 165.88 & 78.72 \\
\hline \multirow{4}{*}{$2^{\mathrm{a}} \mathrm{A}$} & Rep. & 2 & 1440.10 & 747.71 & 124.32 & 0.055 & 696.04 & 440.65 & 15.48 \\
\hline & Bloc/rep (not adjust.) & 9 & $233.73 * *$ & $61.43^{\mathrm{ns}}$ & $94.97 *$ & $0.026^{* *}$ & $232.59^{\text {ns }}$ & $314.79 *$ & $593.66^{* *}$ \\
\hline & Treat. (adjust.) & 15 & $141.61^{*}$ & $70.34 *$ & $102.76^{*}$ & $0.021^{* *}$ & $107.92^{\mathrm{ns}}$ & $97.25^{\mathrm{ns}}$ & $569.95 * *$ \\
\hline & Intrablock error & 21 & 61.19 & 26.32 & 34.90 & 0.007 & 99.05 & 126.69 & 49.33 \\
\hline \multirow{8}{*}{$3^{\mathrm{a}} \mathrm{A}$} & Rep. & 2 & 1440.01 & 747.71 & 124.32 & 0.054 & 696.04 & 440.65 & 15.48 \\
\hline & Bloc/rep (adjust.) & 9 & $135.82^{\text {ns }}$ & $97.22 * *$ & $66.81^{\mathrm{ns}}$ & $0.026^{* *}$ & $236.43 *$ & $257.53^{\text {ns }}$ & $147.30 * *$ \\
\hline & Treat. (adjust.) & 15 & $165.62 * *$ & $77.64 * *$ & $116.83 * *$ & $0.024 * *$ & $112.39^{\mathrm{ns}}$ & $103.74^{\mathrm{ns}}$ & $763.31 * *$ \\
\hline & Intrablock error & 21 & 61.19 & 26.32 & 34.90 & 0.007 & 99.05 & 126.69 & 49.33 \\
\hline & Mean & & 47.15 & 18.26 & 28.88 & 0.384 & 47.24 & 88.68 & 21.62 \\
\hline & $\mathrm{CV}$ lattice intrablock $(\%)$ & & 16.59 & 28.09 & 20.45 & 22.320 & 21.07 & 12.69 & 32.49 \\
\hline & CV block $(\%)$ & & 19.39 & 37.77 & 23.09 & 29.554 & 25.07 & 14.52 & 41.04 \\
\hline & Efficiency (\%) & & 117.26 & 148.36 & 111.46 & 144.370 & 120.59 & 113.63 & 133.03 \\
\hline
\end{tabular}

${ }^{1} \mathrm{TMR}=$ total mass of roots $\left(\mathrm{t} \mathrm{ha}^{-1}\right) ; \mathrm{MCR}=$ mass of commercial roots $\left(\mathrm{tha}^{-1}\right) ; \mathrm{MNR}=$ mass of noncommercial roots $\left(\mathrm{t}\right.$ ha $\left.{ }^{-1}\right) ; \mathrm{PROP}=$ proportion among commercial and total roots; MMTR $=$ means mass of the total roots $\left(\mathrm{g}^{\operatorname{root}^{-1}}\right) ; \mathrm{MMCR}=$ means mass of commercial roots $\left(\mathrm{g}\right.$ root $\left.^{-1}\right)$; $\mathrm{QDF}=$ tolerance to leaf blight (\%).

Table 3 shows the number of ScottKnott averages grouping for the 2014/15 and 2015/16 seasons. Estimates of ' $1{ }^{\mathrm{a}} \mathrm{A}$ ' differ from the other two analyzes. The RCBD analysis, without adjustment of the mean square effect of treatments and, consequently, means of the treatments, results in smaller precision in the average estimates of experiments which the efficiency of lattice is detected, that is, in this situation analysis as a lattice design becomes required. The number of groupings for agricultural year 2014/15 for TMR allocated the means in two groups to ' 1 a $A$ ', while it did not discriminate groups of means for the other two analyzes. Regarding MCR, results were exactly opposite of TMR, with ' $2^{\mathrm{a}} \mathrm{A}$ ' and ' $3{ }^{\mathrm{a}} \mathrm{A}$ ' being more discriminatory. For TMR, the errors were similar for the three analyses and the greater number of error degrees of freedom of the ' 1 a $A$ ' allowed the means test to better discriminate differences between means. For MCR, the lower value of the mean squares of the intrabloc error allowed ' $2 \mathrm{a}$ ' $\mathrm{\text {'and' }} \mathrm{3}^{\mathrm{a}} \mathrm{A}$ ' to be more discriminatory, even though they presented less error degrees of freedom. Regarding TMR and MCR, the latter seems to be more influenced by soil heterogeneity. For this character, the installation of experiments in more complex designs seems more adequate to better detect differences between treatments. For MNR ' 2 a $A$ ' formed two groups of averages whereas for ' 1 a $A$ ' there were three groups, and no clustering for ' $3{ }^{\mathrm{a}} \mathrm{A}$ '. For the proportion of commercial roots on total roots produced (PROP), ' $2{ }^{\mathrm{a}} \mathrm{A}^{\prime}$ ' and ' $3 \mathrm{3}^{\mathrm{a}} \mathrm{A}$ ' were efficient to form different groups of means (three), but ' $1{ }^{\text {a }} \mathrm{A}$ ' did not allow formation of different groups.

For TRMR there were different groups of means with the use of ' 1 a $A$ ' and ' 3 a $A$ ', whereas for ' 2 a $A$ ' there were no groups of means. For MMCR, different groups were not formed by any type of analysis, although the mean square of treatments was significant $(\mathrm{F}=$ 0.05 ), according to analysis of variance of Table 1 for the three types of analyzes. For QDF, '2 ${ }^{\mathrm{a}} \mathrm{A}$ ' and ' $3{ }^{\mathrm{a}} \mathrm{A}$ ' were more efficient than ' $1{ }^{\text {a }} A$ ', as three groups were formed each, whereas for ' $1{ }^{a} A$ ' only two groups were formed.

The greater efficiency in separation of groups depends on character and type of analysis. While for MTMR and MMCR there is no cluster pattern, probably because they are characters less influenced by environment, QDF, that has a very marked interference, since neighboring parcels of treatments with high incidence of burning attack on leaves, are, evidently, more attacked than if they were next to plots without symptoms. In this case the use of lattice design allows to detect and isolate this effect, which reflects in greater discrimination of the groups of averages obtained by ' $2{ }^{a} \mathrm{~A}$ ' and ' 3 a $\mathrm{A}$ '. In addition, Pimentel-Gomes (2009) comments that the use of uncorrected averages, such as happens in an experiment in DBC, is not correct in experiments with proven significance of the effects of blocks within replications, a fact proven in Tables 1 and 2.

Regarding the 2015/16 crop year, for TMR, different categories were formed only when ' 1 a $A$ ' was used. This fact was most probably due to some treatment that benefited from some soil heterogeneity, and this effect was not isolated by the randomized block 
Table 3. Scott-Knott grouping number of the lattice analysis as a randomized complete block $\left(1^{\mathrm{a}} \mathrm{A}\right)$, intrabloc lattice with adjusted treatments $\left(2^{\mathrm{a}} \mathrm{A}\right)$, and intrablock analysis of the lattice with adjusted treatments ( $3^{\mathrm{a}} \mathrm{A}$ ), for 16 carrot hybrids evaluated in the 2014/15 and 2015/16 season. Brasília, Embrapa, 2016.

\begin{tabular}{|c|c|c|c|c|}
\hline \multirow{2}{*}{$\begin{array}{c}\text { Planting } \\
\text { date }\end{array}$} & \multirow{2}{*}{ Caracters } & \multicolumn{3}{|c|}{ Analyses } \\
\hline & & $\mathbf{1}^{\mathrm{a}} \mathrm{A}$ & $2^{\mathrm{a}} \mathrm{A}$ & $3^{\mathrm{a} A}$ \\
\hline \multirow{7}{*}{$2014 / 15$} & $\operatorname{TMR}\left(\mathrm{t} \mathrm{ha}^{-1}\right)^{/ 1}$ & 2 & 1 & 1 \\
\hline & $\operatorname{MCR}\left(\mathrm{t} \mathrm{ha}^{-1}\right)$ & 1 & 2 & 2 \\
\hline & $\operatorname{MNR}\left(\mathrm{t} \mathrm{ha}^{-1}\right)$ & 3 & 2 & 1 \\
\hline & PROP & 1 & 3 & 3 \\
\hline & MTMR $\left(\mathrm{g} \mathrm{root}^{-1}\right)$ & 2 & 1 & 3 \\
\hline & $\operatorname{MMCR}\left(\mathrm{g} \mathrm{root}^{-1}\right)$ & 1 & 1 & 1 \\
\hline & QDF $(\%)$ & 2 & 3 & 3 \\
\hline \multirow{7}{*}{$2015 / 16$} & TMR (t ha-1) & 2 & 1 & 1 \\
\hline & $\operatorname{MCR}\left(\mathrm{t} \mathrm{ha}^{-1}\right)$ & 1 & 1 & 1 \\
\hline & $\operatorname{MNR}\left(\mathrm{t} \mathrm{ha}^{-1}\right)$ & 2 & 2 & 2 \\
\hline & PROP & 1 & 2 & 2 \\
\hline & MTMR $\left(\mathrm{g} \mathrm{root}^{-1}\right)$ & 1 & 1 & 1 \\
\hline & $\operatorname{MMCR}\left(\mathrm{g} \mathrm{root}^{-1}\right)$ & 1 & 1 & 1 \\
\hline & QDF (\%) & 2 & 3 & 3 \\
\hline
\end{tabular}

${ }^{1} \mathrm{TMR}=$ total mass of roots $\left(\mathrm{t} \mathrm{ha}^{-1}\right) ; \mathrm{MCR}=$ mass of commercial roots $\left(\mathrm{t} \mathrm{ha}^{-1}\right) ; \mathrm{MNR}=$ mass of noncommercial roots $\left(\mathrm{t} \mathrm{ha}^{-1}\right)$; $\mathrm{PROP}=$ proportion among commercial and total roots; $\mathrm{MMTR}=$ mean mass of the total roots $\left(\mathrm{g} \mathrm{root}^{-1}\right) ; \mathrm{MMCR}=$ mean mass of commercial roots $\left(\mathrm{g} \mathrm{root}^{-1}\right)$; $\mathrm{QDF}=$ tolerance to leaf blight (\%).

design and reflected in the significance of the mean square of treatments. However, when using more robust designs, the effect of this heterogeneity was isolated at the source of block variation within replications (Table 2). For MCR, although ' 2 a $A$ ' had significant differences between treatments, it was not reflected in formation of different groups of averages by Scott-Knott, probably due to the small number of error degrees of freedom. For MNR the three analyzes revealed similar results and all formed two groups of means.

For PROP and QDF, ' 2 a $A$ ' and ' 3 a A' were more efficient to distinguish between means with the formation of more groups compared to ' 1 a $A$ ', that is, corroborating with discussion that plots more attacked by leaves burn present higher inoculum pressure in their neighboring plots, causing them to present more disease incidence than if they were without pathogen pressure. Also, it is important to emphasize for QDF that the greater number of groups by ' 2 a $A$ ' and ' 3 a $A$ ', makes it easier to identify and select superior genotypes in a breeding program.
CAMPOS, JFD; CARNEIRO, APS ; PETERNELLI, LA; CARNEIRO, JEDS; SILVA, MJD; CECON, PR. 2016. Classification of common bean families under different scenarios of spatial dependence and experimental precision. Pesquisa Agropecuária Brasileira 51: 105-111.

CEAGESP - Companhia de Entrepostos e Armazéns Gerais de São Paulo. 2000. Classificação de cenoura: programa de adesão voluntária. São Paulo: Programa Horti \& Fruti, 1999, 8p.

CEBALLOS-AGUIRRE, N; VALLEJOCABRERA, FA; ARANGO-ARANGO, N. 2012. Evaluación del contenido de antioxidantes en introducciones de tomate tipo cereza (Solanum spp.). Acta Agronómica 61: 230-238.

CONRADO, TV; FERREIRA, DF; SCAPIM, CA; MALUF, WR. 2017 . Adjusting the ScottKnott cluster analyses for unbalanced designs. Crop Breeding and Applied Biotechnology 17: 1-9.

CRUZ, CD. 2013. Genes - a software package for analysis in experimental statistics and quantitative genetics. Acta Scientiarum 35: 271-276.

HAY, FS; PETHYBRIDGE, SJ. 2005. Nematodes associated with carrot production in Tasmania, Australia, and the effect of Pratylenchus crenatus on yield and quality of Kuroda-type carrot. Plant disease 89: 1175-1180.

KHAN, MI; ALI, SHAH, SA; KHAN, M; ULLAH, K; ULLAH, R; KHATAK, SI. 2015. Comparative efficiency of alpha lattice design and complete randomized block design in wheat, maize and potato field trials. Journal of Resources Development and Management 11: 115-117.

MARQUES JÚNIOR, OG; RAMALHO, MAP; FERREIRA, DF. 1999. Emprego do látice no programa de melhoramento do feijoeiro. Ciência e Agrotecnologia 23: 753-759.

MATEI, G; BENIN, G; STORCK, L; MILIOLI, A S; BOZI, AH; DALLÓ, SC; LUCION, RA. 2017. Métodos de análise e número de repetições para ensaios com grande número de genótipos de soja. Ciência Rural 47: 01-07.

MELO PINHEIRO, LC; GOD, PIVG; FARIA, VR; OLIVEIRA, AG; HASUI, AA; PINTO, EHG; MOREIRA, MA. 2013. Parentesco na seleção para produtividade e teores de óleo e proteína em soja via modelos mistos. Pesquisa Agropecuária Brasileira 48: 1246-1253.

NAVARRO, FM; RAK, KT; BANKS, E; BOWEN, BD; HIGGINS, C; PALTA, JP. 2015. Strategies for selecting stable common scab resistant clones in a potato breeding program. American Journal of Potato Research 92: 326-338.

\section{REFERENCES}

BEARZOTI, E; PINTO, CABP; OLIVEIRA, MS 1997. Comparação entre métodos estatísticos na avaliação de clones em um programa de melhoramento de batata. Pesquisa Agropecuária Brasileira 32: 877-884.

BUENO FILHO, JSS; VENCOVSKY, R. 2000. Alternativas de análise de ensaios em látice no melhoramento vegetal. Pesquisa Agropecuária Brasileira 35: 259-269.
NOBREGA， MBDM; GERALDI，IO; CARVAlHO, ADF. 2010. Avaliação de cultivares de mamona em cruzamentos dialélicos parciais. Bragantia 69: 281-288.

NSABIYERA, V; OCHWO-SSEMAKULA, M; SSERUWAGI, P; OJIEWO, C; GIBSON, P. 2013. Combining ability for field resistance hot pepper (Capsicum annuum L.) genotypes in Uganda. International Journal of Plant Breeding,7: 12-21.

PIMENTEL, AJB; SOUZA, MA; CARNEIRO, to disease, fruit yield and yield factors among 
PCS; MACHADO, JC; RIBEIRO, G. 2014. Análise dialélica parcial em gerações avançadas para seleção de populações segregantes de trigo. Pesquisa Agropecuária Brasileira 48: 1555-1561.

PIMENTEL-GOMES, F. 2009. Curso de estatística experimental. 15. ed. Piracicaba: FEALQ, 451p.
SAS Institute. 2014. Base SAS 9.4 Procedures Guide. SAS Institute.

SHARMA, J; GHOSH, DK; PRASAD, J. 2016. Construction of partially balanced incomplete block designs. International Journal of Statistics and Systems 11: 67-76.

SILVA, HD; FERREIRA, DF; PACHECO, CAP. 2000. Avaliação de quatro alternativas de análise de experimentos em látice quadrado, quanto à estimação de componentes de variância. Bragantia 59: 117-123.

VILARINHO, AA; VIANA, JMS; VILARINHO, LBO. 2008. Potencial para melhoramento de populações de milho normal e braquítico obtidas por seleção recorrente recíproca. Revista Ceres 55: 147-152. 